\title{
DNA damage assessment with buccal micronucleus cytome assay in Turkish coal miners
}

\author{
Hatice Gül Anlar ${ }^{1}$, Merve Bacanli², Özlem Kar Kurt ${ }^{3}$, and Canan Eraydin ${ }^{4}$ \\ ${ }^{1}$ Department of Pharmaceutical Toxicology, Faculty of Pharmacy, Zonguldak Bülent Ecevit University, Zonguldak, Turkey \\ ${ }^{2}$ Department of Pharmaceutical Toxicology, Gülhane Faculty of Pharmacy, University of Health Sciences, Ankara, Turkey \\ ${ }^{3}$ Department of Occupational and Pulmonary Medicine, Zonguldak Atatürk State Hospital, Zonguldak, Turkey \\ ${ }^{4}$ Department of Nursing, Faculty of Health Sciences, Zonguldak Bülent Ecevit University, Zonguldak, Turkey
}

[Received in August 2019; Similarity Check in September 2019; Accepted in November 2019]

The aim of this study was to assess DNA damage in Turkish coal miners with the buccal micronucleus cytome (BMCyt assay as the least invasive and therefore most practical method that may find wider application in coal miner biomonitoring. Buccal epithelial cell samples were taken from 54 coal miners and 42 controls from Zonguldak, Turkey to establish their micronucleus (MN), binucleus (BN), condensed chromatin (CC), karyorrhectic (KHC), karyolytic (KYL), nuclear bud (NBUD), and pyknotic (PYC) frequencies. We also analysed the effects of confounding factors such as age, years of work at the mine, smoking, alcohol drinking, and use of protective equipment on differences in $\mathrm{MN}$ frequencies. Two miners had confirmed and three suspect pneumoconiosis, whereas 49 displayed normal chest radiographs. MN, BN, KHC, and NBUD frequencies were significantly higher in coal miners than controls. Years of work at the mine also showed a significant effect on buccal MN frequencies in coal miners, but we found no correlation between MN frequencies and age, smoking, and alcohol consumption. In conclusion, BMCyt assay proved itself an accurate and practical screening method, as it can detect DNA damage much earlier than pneumoconiosis develops.

KEY WORDS: binucleus frequency; coal dust; condensed chromatin frequency; epithelial cells; genotoxicity; industrial health; karryorrhexis; karyolysis; micronucleus frequency; nuclear bud frequency; pyknosis; occupational toxicology

Open-cast coal miners are exposed to coal dust which contains quartz, trace metals, inorganic minerals, and polycyclic aromatic hydrocarbons (PAHs). This exposure can lead to a number of diseases such as pneumoconiosis (black lung disease), progressive massive fibrosis, bronchitis, lung dysfunction, emphysema, and stomach, liver, or lung cancer (1-5).

Several studies of genotoxic and cytogenetic effects of coal dust have shown significantly higher DNA and chromosomal damage in coal miners than in general population (6-9). Coal contains many organic and inorganic compounds. Quartz, one of its major compounds, has been classified as "carcinogen" (Group 1) by the International Agency for Research on Cancer (IARC) due to ample evidence in animals and humans, but coal dust is still "not classifiable as to its carcinogenicity to humans" (Group 3) due to contradictory findings of in vivo and in vitro studies (10). This calls for further research to characterise the risk of coal dust exposure.

A wide range of methods is currently available for the detection of DNA damage due to occupational exposure to chemicals, but most of them are expensive and impractical.

Corresponding author: Hatice Gül Anlar, Department of Pharmaceutical Toxicology, Faculty of Pharmacy, Zonguldak Bulent Ecevit University, 67600, Zonguldak, Turkey, E-mail: haticegulanlar@gmail.com
One of the recent methods that has seen a growing use in assessing the risk of DNA damage and mutation that can evolve into cancer is the buccal micronucleus cytome (BMCyt) assay (11). It is a relatively non-invasive method assessing changes in buccal epithelial cells, which are easy to collect. Buccal epithelial cells are in constant contact with environmental/occupational chemicals such as those in coal dust and epithelial cells in general are the point of origin of most cancers. The BMCyt assay can be used to investigate a variety of toxicological endpoints (12).

Our primary aim was therefore to use it to assess the genotoxic effects of coal dust exposure in Turkish coal miners and see how age, years of work at the mine, smoking, and alcohol consumption might affect micronucleus (MN) frequencies. Our secondary aim was to determine exposure by measuring respirable coal dust levels and to determine the lung function of the exposed miners with chest X-ray imaging and spirometry tests.

\section{PARTICIPANTS AND METHODS}

This study included 54 Turkish male coal miners from the Kozlu Coal Mine, $8 \mathrm{~km}$ to the south-west from the city of Zonguldak. This is the biggest coal mine in Turkey that employs over 6800 miners (13). Our participants were involved in different operations such as surface mining, 
coal beneficiation, dragline operations, and transporter of extracted coal. All of them were exposed to coal dust.

The study also included a control group of 42 men from Zonguldak who were not exposed to any coal dust or chemicals. The two groups were matched in age and lifestyle habits. Possible confounding factors such as smoking, alcohol consumption, years of work at the mine, medical background, and nutritional habits were established in face-to-face interviews with every participant.

The study was approved by the Zonguldak Bulent Ecevit University Clinical Research Ethics Committee (approval no. 2018-111-11-04 of 25 April 2018). All participants were volunteers who signed a written informed consent before they entered the study.

\section{Biological sampling}

All participants rinsed their mouth with water before sampling. Exfoliated buccal epithelial cells were obtained by gently scraping the inside of both cheeks with a wet tongue depressor. The collected cells were smeared directly onto wet slides and then left to dry at room temperature.

\section{Chemicals and equipment}

The chemicals used in this study were purchased from the following suppliers: activated coal, ethanol, fast green, $\mathrm{HCl}$, methanol, pararosaniline, sodium bisulfite, and xylene from Merck Chemicals (Darmstadt, Germany), water bath from Isolab (Eschau, Germany), and light microscope from Olympus (Tokyo, Japan).

\section{Buccal micronucleus cytome (BMCyt) assay}

Slides with collected buccal samples were first fixed in $80 \%$ methanol for $10 \mathrm{~min}$ and dried at room temperature. They were then immersed in $1 \mathrm{~N} \mathrm{HCl}$ at room temperature for $2 \mathrm{~min}$, at $60^{\circ} \mathrm{C}$ for $10 \mathrm{~min}$, and again at room temperature $2 \mathrm{~min}$, followed by washing in distilled water and drying. They were then stained with Feulgen stain (1 g pararosaniline in $100 \mathrm{~mL}$ of distilled water) at room temperature in the dark for $90 \mathrm{~min}$ and washed in distilled water for $5 \mathrm{~min}$. Followed staining in fast green solution $(0.5 \mathrm{~g}$ of fast green in $95 \%$ ethanol) for $10 \mathrm{~s}$, fixed in xylene for $10 \mathrm{~min}$, and finally air-dried in a fume hood. For each participant, 2000 buccal cells (1000 from each of the duplicate slides) were scored by light microscopy as recommended by Sarto et al. (14) and Thomas et al. (15). Cell frequencies were expressed as per thousand $(\%)$.

\section{Radiological examination and spirometry test}

Posteroanterior chest (PA) radiographs of the exposed miners were taken in the radiology clinic of the Turkish Hard Coal Enterprises using short exposure time with high voltage (Dongmun, South Korea). The radiographs were read by a specialist according to the International Labour Office (ILO) classifications (16). The miners were also tested for standard spirometry parameters with a dry-seal spirometer (MIR SpiroLab III, Rome, Italy). Pulmonary function tests were interpreted in accordance with the American Thoracic Society standards (17). They involved forced expression volume in 1 second $\left(\mathrm{FEV}_{1}\right)$, forced vital capacity (FVC), $\mathrm{FEV}_{1} / \mathrm{FVC}$ ratio, and forced mid-expiratory flow rate $\left(\mathrm{FEF}_{25-75 \%}\right)$. Pulmonary restriction is indicated when $\mathrm{FVC}$ and $\mathrm{FEV}_{1}$ values are lower but $\mathrm{FEV}_{1} / \mathrm{FVC}$ ratio is higher than the expected value, while obstruction is indicated when the $\mathrm{FEV}_{1} / \mathrm{FVC}$ ratio is lower than the expected value. Obstructive pattern is also defined as an $\mathrm{FEV}_{1} / \mathrm{FVC}$ ratio below $75 \%$ (18).

\section{Exposure measurements}

Coal dust samples were collected at the respiration level during the daily 8-hour shift with a badge dosimeter (SKC AirCheck 3000 Deluxe, Dorset, United Kingdom). Respirable total dust concentrations were measured in $\mathrm{mg} / \mathrm{m}^{3}$ by gravimetry according to the Health and Safety Executive method MDHS 14/4 (19).

\section{Statistical analysis}

Statistical analysis was done using the computer program SPSS 20.0 for Windows (IBM, Armonk, New York, USA). The normality of data distribution and homogeneity of the variance were tested with the Kolmogorov Smirnov and Levene tests, respectively. Pearson's chi-square test was used to analyse demographical data. Student's $t$-test and Mann Whitney U test were used to determine differences between the groups with and without normal distribution, respectively. Multiple linear regression analysis was used to determine the effects of parameters on the results. Data are expressed as a mean \pm standard deviation for continuous variables and the percentage (\%) for categorical variables. Power of $\mathrm{p}<0.05$ was considered statistically significant.

\section{RESULTS}

\section{Study group demographics}

Table 1 shows the demographic and lifestyle information about the coal miners and control group. The two did not significantly differ in age, smoking, and alcohol habits. The miner group most often complained of ear disorders (such as otitis media and hearing loss) and respiratory disorders (such as asthma, bronchitis, and shortness of breath), but they also complained of waist and neck hernia, callus, and stomach diseases.

\section{BMCyt assay findings}

Micronucleus $(\mathrm{MN})$ frequencies in the epithelial cells of the coal miners were significantly higher than in the control group $(\mathrm{p}<0.05)$. This is also true for the frequencies 
Table 1 General characteristics of coal miners and controls

\begin{tabular}{|c|c|c|c|}
\hline Factors & Controls $(n=42)$ & Workers $(n=54)$ & p values \\
\hline Age (years) ${ }^{a}$ & $39.21 \pm 6.23$ & $39.24 \pm 5.34$ & 0.98 \\
\hline Min-max & $19-48$ & $30-56$ & \\
\hline $19-30$ & 4 & 2 & \\
\hline$\geq 31$ & 38 & 52 & \\
\hline Smokers & 18 & 37 & 0.01 \\
\hline Non-smokers & 24 & 17 & \\
\hline Number of cigarettes smoked ${ }^{\mathrm{a}}$ & $16.0 \pm 6.0$ & $17.02 \pm 9.21$ & \\
\hline Alcohol consumption & & & 0.07 \\
\hline No & 40 & 45 & \\
\hline Yes & 2 & 9 & \\
\hline Years of work at the mine (mean \pm SD) & & $11.93 \pm 5.14$ & \\
\hline Min-max & & $2-27$ & \\
\hline $1-15$ & & 41 & \\
\hline$\geq 16$ & & 13 & \\
\hline \multicolumn{4}{|l|}{ Using Protective Equipment } \\
\hline \multicolumn{4}{|l|}{ Gloves } \\
\hline No & & 1 & \\
\hline Yes & & 53 & \\
\hline \multicolumn{4}{|l|}{ Mask } \\
\hline No & & 3 & \\
\hline Yes & & 51 & \\
\hline \multicolumn{4}{|l|}{ Safety goggles } \\
\hline No & & 14 & \\
\hline Yes & & 40 & \\
\hline \multicolumn{4}{|l|}{ Special clothing } \\
\hline No & & 1 & \\
\hline Yes & & 53 & \\
\hline \multicolumn{4}{|l|}{ ILO category } \\
\hline Silicosis & & 2 & \\
\hline Suspicion of silicosis & & 3 & \\
\hline Normal & & 49 & \\
\hline \multicolumn{4}{|l|}{ Spirometric evaluation } \\
\hline Obstructive pattern & & 4 & \\
\hline Restrictive pattern & & 1 & \\
\hline Normal & & 49 & \\
\hline Medicine use & & & 0.01 \\
\hline No & 42 & 46 & \\
\hline Yes & 0 & 8 & \\
\hline Vitamin-mineral supplementation use & & & 0.03 \\
\hline No & 42 & 51 & \\
\hline Yes & 0 & 3 & \\
\hline
\end{tabular}


of binucleated (BN) cells, karyorrhectic (KHC) cells, and nuclear buds (NBUD) (Table 2).

Older coal miners had significantly higher buccal MN frequencies than younger coal miners $(p<0.05)$, but smoking, alcohol consumption, and use of protective equipment did not correlate with their $\mathrm{MN}$ frequencies (Table 3).

Multiple regression analysis showed significant effects of years of work at the mine on buccal MN frequencies (Table 4).

\section{Chest $X$-ray and spirometry findings}

Two workers had confirmed (diagnosed) and three suspect pneumoconiosis, while the remaining 49 workers

Table 2 Abnormal buccal epithelial cell frequencies (mean \pm SD per 1000 cells)

\begin{tabular}{lccc}
\hline & $\begin{array}{c}\text { Controls } \\
(\mathbf{n}=\mathbf{4 2})\end{array}$ & $\begin{array}{c}\text { Coal } \\
\text { miners } \\
(\mathbf{n}=\mathbf{5 4})\end{array}$ & p values \\
\hline $\mathrm{MN}$ & $3.07 \pm 2.50$ & $\mathbf{8 . 4 6} \pm \mathbf{6 . 8 1 *}$ & $\mathbf{0 . 0 0}$ \\
\hline $\mathrm{BN}$ & $4.21 \pm 3.08$ & $\mathbf{1 0 . 4 4 4} \pm \mathbf{6 . 9 9}$ & $\mathbf{0 . 0 0}^{*}$ \\
\hline $\mathrm{CC}$ & $2.38 \pm 2.68$ & $5.14 \pm 7.16$ & 0.58 \\
\hline KHC & $2.42 \pm 3.68$ & $\mathbf{5 . 4 6} \pm \mathbf{8 . 1 9}$ & $\mathbf{0 . 0 0}^{*}$ \\
\hline KYL & $7.88 \pm 10.52$ & $8.00 \pm 7.46$ & 0.06 \\
\hline PYC & $4.45 \pm 3.42$ & $7.50 \pm 9.18$ & 0.26 \\
\hline NBUD & $0.35 \pm 0.61$ & $\mathbf{0 . 8 1} \pm \mathbf{1 . 0 2}$ & $\mathbf{0 . 0 1}$
\end{tabular}

$* \mathrm{p}<0.05$ compared to controls; $\mathrm{BN}$ cells - binucleated; $\mathrm{CC}-$ condensed chromatin; KHC - karyorrhectic; KYL - karyolytic; NBUD - nuclear bud; PYC - pyknotic; SD - standard deviation

had normal chest X-rays. According to the ILO classification, chest X-rays of the two miners with pneumoconiosis were category 1 and 2 .

Spirometric measurements showed $\mathrm{FEV}_{1} / \mathrm{FVC}$ ratios below $75 \%$ in two coal miners. Four showed signs of mild obstruction and one of mild restriction. Mean $\mathrm{FEV}_{1} / \mathrm{FVC}$ and $\mathrm{FEF}_{25-75 \%}$ were $96.48 \pm 9.98$ and $83.44 \pm 20.66$, respectively.

\section{Exposure measurements}

Respirable total dust levels varied with mining operations involved (sections of the mine) and ranged from 0.57 to $2.81 \mathrm{mg} / \mathrm{m}^{3}$. The mean concentration of total dust was $1.52 \pm 0.37 \mathrm{mg} / \mathrm{m}^{3}$, which is lower than the $5 \mathrm{mg} / \mathrm{m}^{3}$ respirable dust limit for coal mines in Turkey (20).

\section{DISCUSSION AND CONCLUSION}

Miners in our study had significantly higher $\mathrm{MN}, \mathrm{BN}$, $\mathrm{KHC}$, and NBUD frequencies in buccal epithelial cells than controls, and $\mathrm{MN}$ frequencies significantly correlated with years of work at the mine. However, we found no significant effect of smoking and alcohol drinking on buccal MN frequencies. These findings are in line with earlier reports of increased DNA damage in coal workers from different countries $(7,8,21-27)$ and contribute to the limited knowledge about the genotoxic effects of coal dust exposure in Turkish coal miners. One Turkish study (7) with 39 coal workers from the Armutcuk coal mine in the Zonguldak region found significantly higher sister chromatid exchange (SCE), chromosome aberration (CA), and MN frequencies in miners than controls. They also found significant effects of smoking on SCE and MN frequencies and of years of exposure on SCE and CA frequencies. In contrast, another Turkish study (28), which compared lymphocyte SCE and MN frequencies between coal workers $(n=29)$, coal workers with diagnosed pneumoconiosis (CWP, $n=23$ ), and controls reported no significant differences between coal workers and controls but did report significantly higher SCE and $\mathrm{MN}$ frequencies in CWPs than in miners and controls. It also reported no effect of smoking, duration of exposure, and age.

The formation of MN in both lymphocytes and buccal epithelial cells has been used as a useful biomarker to evaluate the genotoxic damage in epidemiological studies (29-31), and our results support that MN formation in buccal epithelial cells is consistent with the model in lymphocytes (32). Most importantly, our findings have pointed out that the BMCyt assay can be very practical and clinically valuable as a method of early detection of DNA damage, long before coal miners develop pneumoconiosis. The majority of our workers had normal chest radiographs and spirometry, even though their buccal MN frequencies were significantly higher than in controls. While it has its limitations, its relatively non-invasive nature allows for more extensive screening of exposed workers to coal dust, even when respirable mean dust levels in the mine are below the Turkish occupational limit of $5 \mathrm{mg} / \mathrm{m}^{3}$, which does not define the content of chemical ingredients in respirable dust. Of course, buccal findings could then be verified by other, more specific and more expensive genotoxicity assays such as comet assay, SCE, and CA tests to better predict DNA damage.

\section{Acknowledgments}

We are grateful to the Turkish Hard Coal Enterprises, the workers and control group. This study was supported by Zonguldak Bulent Ecevit University Scientific Research Project (Grant number: 2018-92436924-01).

\section{Conflict of interest statement}

None to declare. 
Table 3 Buccal MN frequencies in coal miners and controls (mean \pm SD per 1000 cells)

\begin{tabular}{|c|c|c|}
\hline Factors & Controls $(n=42)$ & Workers $(n=54)$ \\
\hline \multicolumn{3}{|l|}{ Age (years) } \\
\hline $19-30$ & $4.40 \pm 7.70$ & $1.50 \pm 0.70$ \\
\hline$\geq 31$ & $2.89 \pm 2.66$ & $8.73 \pm 6.80^{*, * *}$ \\
\hline Smokers & $3.05 \pm 2.33$ & $8.51 \pm 6.61^{*}$ \\
\hline Non-smokers & $3.08 \pm 4.22$ & $8.35 \pm 7.45^{*}$ \\
\hline \multicolumn{3}{|l|}{ Alcohol consumption } \\
\hline No & $3.10 \pm 3.54$ & $8.44 \pm 6.95^{*}$ \\
\hline Yes & $2.50 \pm 3.53$ & $8.44 \pm 6.59$ \\
\hline \multicolumn{3}{|l|}{ Duration of exposure (years) } \\
\hline $1-15$ & & $9.51 \pm 2.61$ \\
\hline$\geq 16$ & & $9.41 \pm 5.75$ \\
\hline \multicolumn{3}{|l|}{ Using Protective Equipment } \\
\hline \multicolumn{3}{|l|}{ Gloves } \\
\hline No & & 9.00 \\
\hline Yes & & $8.43 \pm 6.90$ \\
\hline \multicolumn{3}{|l|}{ Mask } \\
\hline No & & $6.00 \pm 2.64$ \\
\hline Yes & & 8.586 .99 \\
\hline \multicolumn{3}{|l|}{ Safety goggles } \\
\hline No & & $7.00 \pm 5.33$ \\
\hline Yes & & $8.95 \pm 7.28$ \\
\hline \multicolumn{3}{|l|}{ Special clothing } \\
\hline No & & 9.00 \\
\hline Yes & & $8.43 \pm 6.90$ \\
\hline \multicolumn{3}{|l|}{ ILO category } \\
\hline Silicosis & & $10 \pm 1.41$ \\
\hline Suspicion of silicosis & & $10.33 \pm 5.03$ \\
\hline Normal & & $8 \pm 7.08$ \\
\hline \multicolumn{3}{|l|}{ Spirometric evaluation } \\
\hline Obstructive pattern & & $6.75 \pm 4.99$ \\
\hline Restrictive pattern & & 4 \\
\hline Normal & & $9 \pm 7.02$ \\
\hline
\end{tabular}

${ }^{*} \mathrm{p}<0.05$ compared to controls; ${ }^{* *} \mathrm{p}<0.05$ compared between miners. ILO - International Labour Organization; SD - standard deviation

Table 4 Multiple linear regression analysis of studied parameters in miners and controls

\begin{tabular}{lc}
\hline & $\begin{array}{c}\text { Buccal MN frequencies (\%) } \\
\text { B }(95 \% \mathrm{CI})\end{array}$ \\
\hline Age & $-0.1(-0.3$ to 0.1$)$ \\
\hline Alcohol consumption & $0.0(-4.9$ to 2.9$)$ \\
\hline Smoking & $0.0(-2.8$ to 2.1$)$ \\
\hline $\begin{array}{l}\text { Years of work at the } \\
\text { mine }\end{array}$ & $\mathbf{0 . 4}(\mathbf{0 . 2} \text { to } \mathbf{0 . 5})^{*}$
\end{tabular}

${ }^{*} \mathrm{p}<0.05 ; \mathrm{B}$ - regression coefficient (slope); CI - confidence interval

\section{REFERENCES}

1. León-Mejía G, Sosa MQ, Rohr P, Kvitko K, Henriques JAP, Da Silva J. Occupational exposureto coal, genotoxicity, and cancer risk. In: Larramendy ML, Sonia S, editors. Environmental health risk: Hazardous factors to living species. London: InTech; 2016. p. 191-209.

2. Cohen RA, Patel A, Green FH. Lung disease caused by exposure to coal mine and silica dust. Semin Resp Crit Care 2008;29:651-61. doi: 10.1055/s-0028-1101275

3. Ames RG. Gastric cancer and coal mine dust exposure. A case-control study. Cancer 1983;52:1346-50. doi: 10.1002/1097-0142(19831001) 52:7<1346::aidcncr2820520734>3.0.co;2-y 
4. Hosgood HD $3^{\text {rd }}$, Chapman RS, Wei H, He X, Tian L, Liu LZ, Lai H, Engel LS, Chen W, Rothman N, Lan Q. Coal mining is associated with lung cancer risk in Xuanwei, China. Am J Ind Med 2012;55:5-10. doi: 10.1002/ajim.21014

5. Laney AS, Weissman DN. Respiratory diseases caused by coal mine dust. J Occup Environ Med 2014;56(Suppl 10):S18-22. doi: 10.1097/JOM.0000000000000260

6. Šrám R, Hola N, Kotěšovec F, Novakova A. Cytogenetic analysis of peripheral blood lymphocytes in glass workers occupationally exposed to mineral oils. Mutat Res Lett 1985;144:277-80. doi: 10.1016/0165-7992(85)90064-8

7. Donbak L, Rencuzogulları E, Yavuz A, Topaktas M. The genotoxic risk of underground coal miners from Turkey. Mutat Res 2005;588:82-7. doi: $10.1016 / \mathrm{j}$. mrgentox.2005.08.014

8. León-Mejía G, Espitia-Pérez L, Hoyos-Giraldo LS, Da Silva J, Hartmann A, Henriques JA, Quintana M. Assessment of DNA damage in coal open-cast mining workers using the cytokinesis-blocked micronucleus test and the comet assay. Sci Total Environ 2011;409:686-91. doi: 10.1016/j. scitotenv.2010.10.049

9. Savchenko Y, Minina V, Bakanova M, Glushkov A. Genotoxic and carcinogenic effects of industrial factors in coal mining and coal-processing industry. Russ J Genet 2019;55:681-91. doi: 10.1134/S1022795419060140

10. International Agency for Research on Cancer (IARC). Silica, Some Silicates, Coal Dust and para-Aramid Fibrils. IARC Monographs on the Evaluation of Carcinogenic Risks to Humans. Vol 68. Lyon: IARC Press; 1997.

11. Holland N, Bolognesi C, Kirsch-Volders M, Bonassi S, Zeiger E, Knasmueller S, Fenech M. The micronucleus assay in human buccal cells as a tool for biomonitoring DNA damage: the HUMN project perspective on current status and knowledge gaps. Mutat Res 2008;659:93-108. doi: 10.1016/j. mrrev.2008.03.007

12. Bonassi S, Coskun E, Ceppi M, Lando C, Bolognesi C, Burgaz S, Holland N, Kirsh-Volders M, Knasmueller S, Zeiger E, Carnesoltas D, Cavallo D, da Silva J, de Andrade VM, Demircigil GC, Domínguez Odio A, Donmez-Altuntas H, Gattas G, Giri A, Giri S, Gómez-Meda B, Gómez-Arroyo S, Hadjidekova V, Haveric A, Kamboj M, Kurteshi K, Martino-Roth MG, Montero Montoya R, Nersesyan A, Pastor-Benito S, Favero Salvadori DM, Shaposhnikova A, Stopper H, Thomas P, Torres-Bugarín O, Yadav AS, Zúñiga González G, Fenech M. The HUman MicroNucleus project on eXfoLiated buccal cells $\left(\mathrm{HUMN}_{\mathrm{xL}}\right)$ : The role of life-style, host factors, occupational exposures, health status, and assay protocol. Mutat Res 2011;728:88-97. doi: 10.1016/j. mrrev.2011.06.005

13. Turkish Hard Coal Enterprises: Monthly statistical report, April-2019 [displayed 10 June 2019]. Available at http:// www.taskomuru.gov.tr/

14. Sarto F, Finotto S, Giacomelli L, Mazzotti D, Tomanin R, Levis AG. The micronucleus assay in exfoliated cells of the human buccal mucosa. Mutagenesis 1987;2:11-7. doi: 10.1093/mutage/2.1.11

15. Thomas P, Holland N, Bolognesi C, Kirsch-Volders M, Bonassi S, Zeiger E, Knasmueller S, Fenech M. Buccal micronucleus cytome assay. Nat Protoc 2009;4:825-37. doi: 10.1038 /nprot.2009.53

16. International Labour Organisation (ILO). Guidelines for the use of the ILO International Classification of Radiographs of Pneumoconioses. Revised edition 2011. Geneva: ILO; 2011.

17. Miller MR, Hankinson J, Brusasco V, Burgos F, Casaburi R, Coates A, Crapo R, Enright P, van der Grinten CP, Gustafsson P, Jensen R, Johnson DC, MacIntyre N, McKay R, Navajas D, Pedersen OF, Pellegrino R, Viegi G, Wanger J; ATS/ERS Task Force. Standardisation of spirometry. Eur Respir J 2005;26:319-38. doi: 10.1183/09031936.05.00034805

18. Bateman ED, Hurd SS, Barnes PJ, Bousquet J, Drazen JM, FitzGerald JM, Gibson P, Ohta K, O'Byrne P, Pedersen SE, Pizzichini E, Sullivan SD, Wenzel SE. Global strategy for asthma management and prevention: GINA executive summary. Eur Respir J 2008;31:143-78. doi: 10.1183/09031936.00138707

19. Health and Safety Executive. General methods for sampling and gravimetric analysis of respirable, thoracic and inhalable aerosols [displayed 10 July 2019]. Available at http://www. hse.gov.uk/pubns/mdhs/pdfs/mdhs14-4.pdf

20. [Dust Control Regulation, in Turkish]. Pub. L. No. 28812, Official Gazette [displayed 5 November 2013]. Available at https://www.resmigazete.gov.tr/eskiler/2013/11/20131105-9. htm

21. Celik M, Donbak L, Unal F, Yüzbasioglu D, Aksoy H, Yilmaz S. Cytogenetic damage in workers from a coal-fired power plant. Mutat Res 2007;627:158-63. doi: 10.1016/j. mrgentox.2006.11.003

22. Schins RPF, Schilderman PAEL, Borm PJA. Oxidative DNA damage in peripheral blood lymphocytes of coal workers. Int Arch Occup Environ Health 1995;67:153-7. doi: 10.1007/ bf00626346

23. Schoket B, Poirier MC, Mayer G, Török G, KolozsiRingelhann A, Bognár G, Bigbee WL, Vincze I. Biomonitoring of human genotoxicity induced by complex occupational exposures. Mutat Res 1999;445:193-203. doi: 10.1016/ s1383-5718(99)00126-6

24. Sinitsky MY, Minina VI, Gafarov NI, Asanov MA, Larionov AV, Ponasenko AV, Volobaev VP, Druzhinin VG. Assessment of DNA damage in underground coal miners using the cytokinesis-block micronucleus assay in peripheral blood lymphocytes. Mutagenesis 2016;31:669-75. doi: 10.1093/ mutage/gew038

25. Minina VI, Sinitsky M, Kulemin E, Volobaev VP, Savchenko YA. Genotoxic effects of coal dust on Kuzbass workers. Chem Sustain Develop 2016;24:545-8. doi: 10.15372/ KhUR20160414

26. León G, Sosa M, Debastiani R, Dias J, Espitia-Pérez L, Hartmann A, Henriques JA, Da Silva J. Genetic damage in coal miners evaluated by buccal micronucleus cytome assay. Ecotoxicol Environ Saf 2014;107:133-9. doi: 10.1016/j. ecoenv.2014.05.023

27. Rohr P, da Silva J, da Silva FR, Sarmento M, Porto C, Debastiani R, Dos Santos CE, Dias JF, Kvitko K. Evaluation of genetic damage in open-cast coal mine workers using the buccal micronucleus cytome assay. Environ Mol Mutagen 2013;54:65-71. doi: 10.1002/em.21744

28. Ulker OC, Ustundag A, Duydu Y, Yucesoy B, Karakaya A. Cytogenetic monitoring of coal workers and patients with coal workers' pneumoconiosis in Turkey. Environ Mol Mutagen 2008;49:232-7. doi: 10.1002/em.20377

29. Diler SB, Celik A. Cytogenetic biomonitoring of carpet fabric workers using micronucleus frequency, nuclear changes, and the calculation of risk assessment by repair index in exfoliated 
mucosa cells. DNA Cell Biol 2011;30:821-7. doi: 10.1089 dna.2011.1216

30. Rohr P, Kvitko K, da Silva FR, Menezes APS, Porto C, Sarmento M, Decker N, Reyes JM, Allgayer Mda C, Furtado TC, Salvador M, Branco C, da Silva J. Genetic and oxidative damage of peripheral blood lymphocytes in workers with occupational exposure to coal. Mutat Res 2013;758:23-8. doi: 10.1016/j.mrgentox.2013.08.006

31. Kirsch-Volders M, Bonassi S, Knasmueller S, Holland N, Bolognesi C, Fenech MF. Commentary: Critical questions, misconceptions and a road map for improving the use of the lymphocyte cytokinesis-block micronucleus assay for in vivo biomonitoring of human exposure to genotoxic chemicals - A HUMN project perspective. Mutat Res 2014;759:49-58. doi: 10.1016/j.mrrev.2013.12.001

32. Ceppi M, Biasotti B, Fenech M, Bonassi S. Human population studies with the exfoliated buccal micronucleus assay: Statistical and epidemiological issues. Mutat Res 2010;705:11-9. doi: 10.1016/j.mrrev.2009.11.001

\section{Procjena oštećenja DNA bukalnih epitelnih stanica primjenom Cytome inačice mikronukleus-testa}

Cilj je ovoga istraživanja bio procijeniti oštećenje DNA u turskih rudara primjenom tzv. Cytome inačice mikronukleustesta na bukalnim epitelnim stanicama (engl. buccal micronucleus cytome assay, krat. BMCyt) kao najmanje invazivne i stoga najpraktičnije metode koja bi mogla naći svoju primjenu u biomonitoringu rudara u ugljenokopima. Uzorci bukalnih epitelnih stanica prikupljeni su od 54 rudara i 42 kontrolna ispitanika iz Zonguldaka u Turskoj radi utvrđivanja učestalosti mikronukleusa (MN), binuklearnih stanica (BN), zgusnutoga kromatina (CC), karioreksije (KHC), kariolize (KYL), jezgrinih pupova (NB) i piknoze (PYC). Osim toga, analizirali smo koliko čimbenici poput dobi, godina staža u rudniku, pušenja, pijenja alkohola i uporabe zaštitne opreme utječu na razlike u nalazima učestalosti MN-a. Dva su rudara imala potvrđenu dijagnozu pneumokonioze, u tri je rudara postojala sumnja na nju, a ostalih 49 rudara imalo je uredne rendgenske nalaze. Učestalosti MN-a, BN-a, KHC-a i NB-a bile su značajno više u rudara nego u kontrolnih ispitanika. Godine staža u rudniku također su značajno pridonijele povišenoj učestalosti MN-a u rudara, ali takva korelacija nije utvrđena za dob, pušenje i pijenje alkohola. BMCyt test pokazao se preciznim i praktičnim probirnim testom jer otkriva oštećenje DNA mnogo ranije nego što se pojavi pneumokonioza.

KLJUČNE RIJEČI: binuklearne stanice; epitelne stanice; genotoksičnost; karioliza; karioreksija; mikronukleus; piknoza; jezgrini pupovi; toksikologija radne sredine; ugljena prašina; zdravlje u industriji; zgusnuti kromatin 